\title{
Comparison of Quantitative Endotoxin against 5 Species of Enterobacteriaceae
}

\author{
Pil Seung Kwon
}

Department of Clinical Laboratory Science, Wonkwang Health Science University, Iksan 54538, Korea

\section{장내세균 5종의 Endotoxin 정량 비교}

\author{
권필승
}

원광보건대학교 임상병리과

\begin{abstract}
Endotoxin, also known as lipopolysaccharide (LPS) produced by the cell wall of gram negative bacteria can be present in any liquid or on any biomaterial. Endotoxin in blood can cause fever and inflammation. In this study, we compared bacterial endotoxin using Escherichia coli 0157:H7, Klebsiella oxytoca, Salmonella Typhi, Shigella sonnei and Morganella morganii. Bacteria were cultured for use in the experiment, and diluted to $1.5 \times 10^{8} \mathrm{CFU} / \mathrm{mL}$. A check marked sensitivity confirmatory test of the Limulus amebocyte lysate ( $\mathrm{LAL}$ ) reagent was performed to examine the validity. The end point reaction to each bacteria sample was confirmed with 10 fold dilution and then the final reaction end point was confirmed by 2 fold dilution between the dilution step and the upper dilution step. According to the results, in detection of endotoxins in more than $0.015 \mathrm{EU} / \mathrm{mL}$, E. coli 0157 was $75 \sim 37.5 \mathrm{CFU} / \mathrm{mL}$, K. oxytoca 37.5 18.75 CFU/mL, M. morganii and S. Typhi $3.75 \sim 1.875 \mathrm{CFU} / \mathrm{mL}$, and $S$. sonnei $7.5 \sim 3.75 \mathrm{CFU} / \mathrm{mL}$. The resulting value was finally ensured by a confirmation test for the inhibitory factor. Based on this study, conduct of further research on bacterial endotoxin is encouraged.
\end{abstract}

Keywords: Endotoxin, Lipopolysaccharide, Limulus amebocyte lysate, Enterobacteriaceae

This is an Open Access article distributed under the terms of the Creative Commons Attribution Non-Commercial License (http://creativecommons.org/licenses/by-nc/4.0) which permits unrestricted non-commercial use, distribution, and reproduction in any medium, provided the original work is properly cited.

Copyright ( 2016 The Korean Society for Clinical Laboratory Science. All rights reserved.
Corresponding author: Pil Seung Kwon Department of Clinical Laboratory Science, Wonkwang Health Science University, 514 Iksandae-ro, Iksan 54538, Korea Tel: 82-63-840-1212

Fax: 82-63-840-1219

E-mail: pskwon@wu.ac.kr

Received: May 1, 2016 Revised 1 $1^{\text {st. }}$ May 16, 2016 Revised 2 ${ }^{\text {nd. }}$ : May 18, 2016 Accepted: May 20, 2016

\section{서 론}

Lipopolysaccharide (LPS)는 그람음성 세균의 세포벽의 바깥쪽 구성성분 중 하나이며[1], 친수성의 O-specific polysaccharide와 core oligosaccharide, 소수성의 lipid A로 구성되어 있다. 이러한 LPS는 세균의 사멸로 인하여 세포벽이 파괴되었을 때 방출되며 세 균 내독소(endotoxin)라고 불리울 만큼 생체 내에서 pathogen으 로 작용이 된다. 가장 두드러지는 증상으로는 혈관 내로 침투되었을 때 발열을 일으키는 것이다. 단핵구와 대식세포가 탐식작용을 통하 여 LPS를 분해하고 이때 방출되는 interleukin-1은 임파구를 통하 여 시상하부의 체온조절 중추를 자극하여 발열반응을 유도시키는
것이다[2]. 또한 LPS는 치사성 쇼크, 체중감소, macrophage 활성 화 등의 다양한 증상을 일으키기도 한다[3-5]. LPS는 $200^{\circ} \mathrm{C}$ 까지도 변성되지 않을 만큼 화학적으로 열에 매우 안정한 구조를 가지고 있 어 일반적인 고온고압증기멸균에 의해 제거되지 않는다. 단 알칼리 용액에서는 불활성화가 가능하다[6]. 제약회사에서는 의약품의 $\mathrm{LPS}$ 를 검출하는 방법으로 주로 토끼를 이용하여 항문의 체온을 측 정하는 pyrogen test를 이용해왔으나 1960년대부터는 투구 게의 혈구성분 중 하나인 Limulus amebocyte lysate (LAL)이 LPS에 특 이적으로 반응한다는 특성을 이용하여 정량하는 LAL test가 개발되 었다. LAL test는 기존의 토끼를 이용한 발열성 시험보다 경제성이 높고 감도가 우수하며 신속하고 정량이 가능하다는 점으로 인하여 
점차 발열성 시험을 대체할 수 있는 시험으로 대두되고 있다[7-9]. 본 연구에서는 병원성이 있는 그람음성 막대균 중 장내세균인 Escherichia coli O157:H7 (E. coli O157), Klebsiella oxytoca, Salmonella Typhi, Shigella sonnei, Morganella morganif를 사용 하였다. E. coli $\mathrm{O} 157$ 은 출혈성 장염의 원인균이며 미국 Oregon주 등에서 햄버거를 매개체로 발생한 집단 식중독을 일으킨 균이다 [10]. 혈전성 혈소판감소증 등의 증상을 보이는 용혈성 요독증후군 의 원인균으로 유아에게 감염이 특히 문제시 된다[11]. K. oxytoca 는 폐렴 및 요로감염증 등의 질병을 야기시키는 균으로 여러 항생제 에 강한 내성을 가지고 있다. 또한 E. coli에 이어 두 번째로 많이 감염 이 되는 균으로 알려져 있으며 요로감염증의 $17 \%$ 까지 차지하기도 한다. 이러한 Klebsiella spp.는 물, 토양, 식물 등의 보편적인 환경 에서 발견이 되지만 척추동물에서도 발견이 되는 매우 흔한 균이다 [12]. S. Typhi는 사람을 유일한 숙주로 하는 장티프스의 원인균으 로 열과 복통이 온몸에 걸쳐 나타나는 증상을 보인다[13]. S. sonnei 는 이질균으로 알려져 있으며 감염초기에 대부분의 환자에서 수양 성 설사를 일으키기도 하는데 일반적으로 건강한 성인에서는 자연 치유 된다[14]. M. morganii는 주로 요로 감염을 일으킨다. 중추신 경계 감염을 일으키는 경우는 극히 드물며 면역이 저하되거나 신생 아에서의 감염이 보고되어 있다[15-17]. 이러한 장내세균들은 모 두 그람음성 세균이기에 endotoxin을 보유하고 있지만, 그 정도에 대한 차이에 대하여는 아직까지 보고된 바가 없다. 본 연구를 통하여 장내세균들의 endotoxin 보유량을 측정하고 비교하려 한다.

\section{재료 및 방법}

\section{1. 검체준비}

대상균주인 E. coli O157, K. oxytoca, S. Typhi, S. sonnei, M. morganii는 모두 단국대학교병원 미생물검사실에서 VITEK II 시 스템(bioMerieux, Marcyl'Etoile, France)으로 동정된 균주를 사 용하였다. 초저온 냉동고에 보관된 균주를 꺼내어 실온이 되도록 녹인 후 MacConkey agar에 도말 한 후 산소성 incubater (Jeio $\mathrm{Tech}, \mathrm{MA}, \mathrm{USA}) 35^{\circ} \mathrm{C}$ 에서 24 시간 동안 배양하고 생성된 집락 1 개 를 취하여 Mueller-Hinton broth (Difco, MI, USA) $2 \mathrm{~mL}$ 에 현탁 시켰다. $1.5 \times 10^{8} \mathrm{CFU} / \mathrm{mL}$ 가 되는 $0.5 \mathrm{MacFarland}$ 표준값을 VITEK사의 densicheck으로 측정하여 모든 균주의 농도를 보정하 였다. 동일한 농도로 보정한 균주들은 모두 Heating block $100^{\circ} \mathrm{C}$ 로 균체를 사멸시켜 세포벽내의 LPS가 방출되게끔 하였다.

\section{2. $\mathrm{LAL}$ 시약의 표시감도 확인시험}

본 연구에서 사용되어진 LAL 시약(Charles liver, Califonia,
$\mathrm{USA}$ )의 표시감도인 $0.015 \mathrm{EU} / \mathrm{mL}$ 의 표시감도를 확인하기 위하여 Control standard endotoxin (CSE)를 LAL reagent water (LRW) 로 $0.03,0.015,0.00725,0.00375 \mathrm{EU} / \mathrm{mL}$ 로 희석하였다. 희석된 용액을 pyrogen free로 확인된 유리관으로 옮긴 후 각각의 희석액 $100 \mu \mathrm{L}$ 에 동량의 LAL 시약을 첨가하고 Heating block을 이용하여 $37^{\circ} \mathrm{C}$ 로 60 분간 유지한 후 유리관을 진동이 없게끔 조심스레 $180^{\circ}$ 로 돌려 내용물을 관찰하였다. 흘러내리지 않는 견고한 겔이 형성 되어 있을 때 양성으로 판정하였다(Fig. 1). 총 4회 실험하여 검증하 였으며 매회 시험에서 $0.00375 \mathrm{EU} / \mathrm{mL}$ 만 모두 음성을 나타낼 경우 본 시험은 유효한 것으로 하였다.

\section{Endotoxin 정량시험}

각 세균들을 10 fold dilution하여 1차 시험을 진행하였다. 정량 시험을 위한 검액인 첫번째 군은 유리관에 10 fold dilution한 각 샘 플들 $100 \mu \mathrm{L}$ 와동량의 $0.015 \mathrm{EU} / \mathrm{mL}$ 의 감도를 가진 LAL시약을 넣 었다. 두번째 군은 양성대조군으로 첫번째 군과 동일한 상태에서 $0.015 \mathrm{EU} / \mathrm{mL}$ 의 CSE를 첨가하였다. 세번째 군은 음성대조군으로 $\mathrm{LRW}$ 에 동량의 LAL 시약을 첨가하였다. $37^{\circ} \mathrm{C}$ 에서 60 분간 반응시 킨 후 두번째 군의 결과가 모두 양성이고 세번째 군의 결과가 모두 음성일 때 유효한 시험으로 하였으며 1차 시험 후 정확하게 겔화를 보인 농도부터 그 이전 농도까지를 2 fold dilution하여 동일한 방 법으로 2차 시험을 진행하여 최종 농도를 확인하였다. 모든 실험은 2회 반복시험 하였고 2회에서 결과가 차이가 있을 경우 재시험을 실시하였다.

\section{4. 반응간섭인자 시험}

검액에 대하여 반응을 촉진 또는 저해하는 인자의 유무를 조사 하기 위하여 반응간섭인자 시험을 진행하였다. 반응간섭인자 시험 을 위한 첫번째 군은 음성대조군으로 정량시험에서 최종 설정된 반 응 end point 농도의 시액 $100 \mu \mathrm{L}$ 와 동량의 LAL시약만을 첨가하
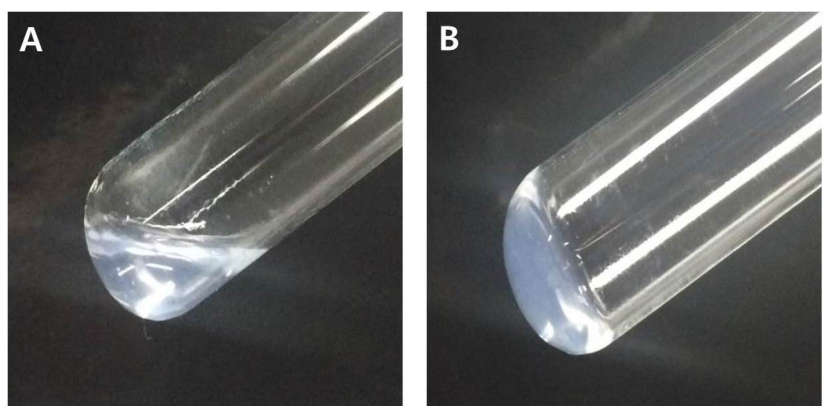

Fig. 1. Determination of the gel clot endotoxin test. (A) Negative and (B) positive. 
였다. 반응간섭인자 시험을 위한 $\mathrm{CSE}$ 를 첨가한 두번째 군은 0.03 $\mathrm{EU} / \mathrm{mL}$ 의 $\mathrm{CSE}$ 와 검액을 섞은 후 2, 4, 8 배 희석하고 각각의 용액 $100 \mu \mathrm{L}$ 에 동량의 LAL시약을 넣었다. 세번째 군은 LRW $100 \mu \mathrm{L}$ 와 동량의 LAL시약을 넣었다. 모든 $37^{\circ} \mathrm{C}$ 에서 60 분간 반응시킨 후 첫 번째 군과 세번째 군이 모두 음성을 나타내고 두번째 군의 시험결 과가 $0.00375 \sim 0.03 \mathrm{EU} / \mathrm{mL}$ 의 범위에 있을 때 검액의 반응간섭인 자가 존재하지 않는 것으로 판정하였다.

\section{결 과}

\section{LAL 시약의 표시감도 확인시험}

본 연구에서 사용되어진 LAL 시약의 표시감도를 확인하기 위하 여 본 시험을 진행하였다. LAL 표기시약의 표시감도는 표기대로 $0.015 \mathrm{EU} / \mathrm{mL}$ 이었으며 LRW는 오염되지 않은 것을 확인하였다 (Table 1).

\section{Endotoxin 정량시험}

1 차시험 결과 각 균주는 모두 최초 원액에서 $10^{7}$ 배 희석한 $1.5 \times 10^{2} \mathrm{CFU} / \mathrm{mL}$ 농도에서는 모두 양성반응으로 $0.015 \mathrm{EU} / \mathrm{mL}$ 이상의 endotoxin 함유량을 확인하였고 $10^{8}$ 배 희석한 $1.5 \times 10^{1}$

Table 1. Check marked sensitivity test

\begin{tabular}{ccl}
\hline & CSE concentration $(\mathrm{EU} / \mathrm{mL})$ & Reaction \\
\hline CSE+LAL reagent & 0.03 & Positive \\
& 0.015 & Positive \\
& 0.00725 & Negative \\
LRW+LAL regent & 0.00375 & Negative \\
\hline
\end{tabular}

Abbreviation: CSE, control standard endotoxin; LAL, limulus amebocyte lysate; LRW, LAL reagent water.

Table 2. The primary quantitative testsof endotoxin

\begin{tabular}{cccl}
\hline & $\begin{array}{c}\text { Bacteria concentration } \\
(\mathrm{CFU} / \mathrm{mL})\end{array}$ & $\begin{array}{c}\text { Positive } \\
\text { control }\end{array}$ & Reaction \\
\hline $\begin{array}{c}\text { E. Coli O157+LAL } \\
\text { reagent }\end{array}$ & $1.5 \times 10^{8} \sim 1.5 \times 10^{2}$ & Positive & Positive \\
$1.5 \times 10^{1}$ & Positive & Negative \\
K. oxytoca+LAL & $1.5 \times 10^{8} \sim 1.5 \times 10^{2}$ & Positive & Positive \\
reagent & $1.5 \times 10^{1}$ & Positive & Negative \\
M. morganï+LAL & $1.5 \times 10^{8} \sim 1.5 \times 10^{1}$ & Positive & Positive \\
reagent & $1.5 \times 10^{0}$ & Positive & Negative \\
S. Typhi+LAL & $1.5 \times 10^{8} \sim 1.5 \times 10^{1}$ & Positive & Positive \\
reagent & $1.5 \times 10^{0}$ & Positive & Negative \\
S. sonnei+LAL & $1.5 \times 10^{8} \sim 1.5 \times 10^{1}$ & Positive & Positive \\
reagent & $1.5 \times 10^{0}$ & Positive & Negative \\
RLW+LAL reagent & 0 & Positive & Negative \\
\hline
\end{tabular}

Abbreviation: CFU, colony forming units; LAL, limulus amebocyte lysate; LRW, LAL reagent water.
$\mathrm{CFU} / \mathrm{mL}$ 의 농도에서는 E. coli $\mathrm{O} 157$ 와 K. oxytoca는 음성 반응을 보였지만, M. morganii, S. Typhi, S. sonnei는 양성 반응을 보였 다. 이에 M. morganii, S. Typhi, S. sonnei는 $10^{9}$ 배 희석하여 $1.5 \times 10^{0} \mathrm{CFU} / \mathrm{mL}$ 에서의 결과 값을 확인한 결과 모두 음성반응을 보였다. 결론적으로 M. morganii, S. Typhi, S. sonnei 각각의 균주 0.15 1.5 CFU/mL가 $0.015 \mathrm{EU} / \mathrm{mL}$ 의 endotoxin을 보유하고 있 으며 E. coli $\mathrm{O} 157$ 와 K. oxytoca는 1.5 15 CFU/mL가 0.015 $\mathrm{EU} / \mathrm{mL}$ 의 endotoxin을 보유하고 있었다. 2회 반복시험 모두 동일 한 결과를 보였다(Table 2). 2차시험은 1차시험결과를 토대로 설정 된 범위에서 2 fold dilution을 진행하여 시험을 실시하였다. E. coli O157와 K. Oxytoca는 $7.5 \times 10^{1}, 3.75 \times 10^{1}, 1.875 \times 10^{1}$ $\mathrm{CFU} / \mathrm{mL}$ 의 농도로 진행하였으며 M. morganii, S. Typhi, $S$. Sonnei는 $7.5 \times 10^{0}, 3.75 \times 10^{0}, 1.875 \times 10^{0} \mathrm{CFU} / \mathrm{mL}$ 의 농도로 진행하였다. E. coli $\mathrm{O} 157$ 은 $3.75 \times 10^{1} \mathrm{CFU} / \mathrm{mL}$ 이 반응 end point로 음성반응을 보였고, K. oxytoca는 $1.875 \times 10^{1} \mathrm{CFU} / \mathrm{mL}$, M. morganii와 $S$. Typhi는 $1.875 \times 10^{\circ} \mathrm{CFU} / \mathrm{mL}$, S. sonnei는 $3.75 \times 10^{0} \mathrm{CFU} / \mathrm{mL}$ 이 반응 end point로 음성반응을 보였다 (Table 3). E. coli O157은 75 37.5 CFU/mL, K. oxytoca는 37.5 $\sim 18.75 \mathrm{CFU} / \mathrm{mL}$, M. morganii와 S. Typhi는 3.75 1.875 $\mathrm{CFU} / \mathrm{mL}, S$. sonnei는 7.5 3.75 CFU/mL가 $0.015 \mathrm{EU} / \mathrm{mL}$ 의 endotoxin을 보유하고 있었다(Fig. 2).

\section{3. 반응간섭인자 시험}

$0.015 \mathrm{EU} / \mathrm{mL}$ 의 감도를 가지는 LAL 시약과 각각의 세균의 반응 end point 농도에서 간섭되는 인자에 대한 확인시험을 진행하였다. 해당 균주의 반응 end point농도에 CSE를 농도별(0.03, 0.015, $0.0725,0.0375 \mathrm{EU} / \mathrm{mL})$ 로 첨가 한 후 $\mathrm{LAL}$ 시약을 동량 처리하여 반 응시켰다. 모든 시험에서 정해진 시약의 감도대로 결과를 보여 각 균 주들은 반응에 간섭되는 인자는 없는 것을 확인하였다(Table 4).

Table 3. The second quantitative tests of endotoxin

\begin{tabular}{lccl}
\hline & $\begin{array}{c}\text { Bacteria concentration } \\
(\mathrm{CFU} / \mathrm{mL})\end{array}$ & $\begin{array}{c}\text { Positive } \\
\text { control }\end{array}$ & Reaction \\
\hline $\begin{array}{l}\text { E. Coli } 0157+\mathrm{LAL} \\
\text { reagent }\end{array}$ & $7.5 \times 10^{1}$ & Positive & Positive \\
K. oxytoca+LAL & $7.75 \times 10^{1}$ & Positive & Negative \\
reagent & $3.5 \times 10^{1}$ & Positive & Positive \\
M. morganii+LAL & $7.5 \times 10^{\circ} \sim 3.75 \times 10^{\circ}$ & Positive & Negative \\
reagent & $1.875 \times 10^{\circ}$ & Positive & Positive \\
S. Typhi+LAL & $7.5 \times 10^{0} \sim 3.75 \times 10^{\circ}$ & Positive & Positive \\
reagent & $1.875 \times 10^{0}$ & Positive & Negative \\
S. sonnei+LAL & $7.5 \times 10^{\circ}$ & Positive & Positive \\
reagent & $3.75 \times 10^{\circ}$ & Positive & Negative \\
RLW+LAL reagent & 0 & Positive & Negative \\
\hline
\end{tabular}

See Table 2. 


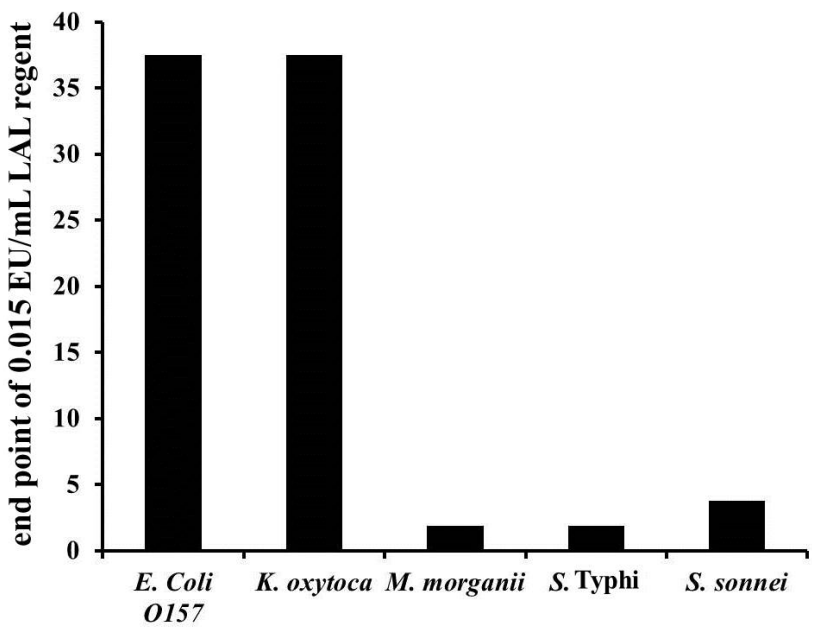

Fig. 2. Comparison of end point each bacteria.

\section{고 찰}

일반적으로 endotoxin을 확인하는 LAL 시약은 gel 형성 여부에 따라 판정하는 gel clot법과 gel이 형성되면서 변화되는 탁도를 측 정하는 비탁법, 응고효소에 의해 기질로부터 유리되는 발색을 측정 하는 비색법이 있다. Gel clot법은 시약과 Heating block으로만 시 험이 가능하여 간편하고 경제적이지만 gel화의 정도에 대한 판정 이 불분명하고 정량시험을 위해서는 많은 시험을 진행해야 한다는 단점이 있다. 비탁법은 일정시간 내에 도달하는 최종 탁도를 측정 하는 end-point 비탁법과 특정 탁도로 도달되는데 필요한 시간을 측정하는 kinetic 비탁법이 있다. 비색법 역시 비탁법과 동일하게 최종 탁도를 측정하거나 특정 탁도로 도달되는 데에 필요한 시간을 측정하는 방법들이 있다. 비색법과 비탁법은 정확도가 높고 정량시 험을 하기에는 적합하지만 측정을 위하여 정해진 장비를 사용하여 야 하기 때문에 경제적이지는 못하며 전처리에 번거로움이 있어 간 편하지 못하다. 세균의 내독소가 투구 게의 혈구성분인 LAL와 만나 면 serine protease zymogen 들이 효소반응을 시작하고 Amebocyte coagulogen을 변화시켜 coagulin gel을 생성한다. 또한 limulus clotting enzyme의 LPS 매게 활성을 조절한다[18]. 하지만 다른 각도에서 보면 LAL시약이 LPS이외에도 다른 특정물 질들과 반응될 수도 있다는 것이 보고되고 있다[18-20]. 본 연구에 서는 간편하며 경제적인 방법인 gel clot법을 사용하였다. 본 연구 는 직접적으로 세균에 대하여 검사한 것이므로 외부 간섭인자가 거 의 없었다. 하지만 혈청에서 세균내독소를 검사할 경우에는 여러가 지 matrix effect로 인하여 검사에 오류를 줄 수 있어 내독소가 단백 질이 변성되는 고열에서 안정하다는 특성을 이용하여 $80^{\circ} \mathrm{C}$ 로 가열 한 후 검사를 진행한다. 이러한 처리만으로도 부족하여 $100^{\circ} \mathrm{C}$ 로 끓 인 후 원심분리하여 검사하는 방법도 보고되어 있다[21]. 하지만 세
Table 4. Reaction interference factor test

\begin{tabular}{|c|c|c|}
\hline & $\begin{array}{c}\text { CSE concentration } \\
(\mathrm{EU} / \mathrm{mL})\end{array}$ & Reaction \\
\hline \multirow{5}{*}{$\begin{array}{l}\text { E. Coli } 0157\left(3.75 \times 10^{1}\right. \\
\text { CFU } / \mathrm{mL})+\mathrm{LAL} \text { reagent }\end{array}$} & 0 & Negative \\
\hline & 0.03 & positive \\
\hline & 0.015 & Positive \\
\hline & 0.0725 & Negative \\
\hline & 0.0375 & Negative \\
\hline \multirow{5}{*}{$\begin{array}{l}\text { K. oxytoca }\left(3.75 \times 10^{1}\right. \\
\text { CFU } / \mathrm{mL})+\mathrm{LAL} \text { reagent }\end{array}$} & 0 & Negative \\
\hline & 0.03 & Positive \\
\hline & 0.015 & Positive \\
\hline & 0.0725 & Negative \\
\hline & 0.0375 & Negative \\
\hline \multirow{5}{*}{$\begin{array}{l}\text { M. morganii }\left(1.875 \times 10^{0}\right. \\
\text { CFU } / \mathrm{mL})+\mathrm{LAL} \text { reagent }\end{array}$} & 0 & Negative \\
\hline & 0.03 & Positive \\
\hline & 0.015 & Positive \\
\hline & 0.0725 & Negative \\
\hline & 0.0375 & Negative \\
\hline \multirow{5}{*}{$\begin{array}{l}\text { S. Typhi }\left(1.875 \times 10^{0}\right. \\
\text { CFU } / \mathrm{mL})+L A L \text { reagent }\end{array}$} & 0 & Negative \\
\hline & 0.03 & Positive \\
\hline & 0.015 & Positive \\
\hline & 0.0725 & Negative \\
\hline & 0.0375 & Negative \\
\hline \multirow{5}{*}{$\begin{array}{l}\text { S. sonnei }\left(3.75 \times 10^{0}\right. \\
\text { CFU } / \mathrm{mL})+L A L \text { reagent }\end{array}$} & 0 & Negative \\
\hline & 0.03 & Positive \\
\hline & 0.015 & Positive \\
\hline & 0.0725 & Negative \\
\hline & 0.0375 & Negative \\
\hline$R L W+L A L$ reagent & 0 & Negative \\
\hline
\end{tabular}

See Table 2.

균내독소의 검사에 대한 연구는 국내외에 아직까지 많지 않기에 좀 더 확실한 연구와 kit 개발이 시급한 실정이다. 측정결과 E. coli O157와 K. oxytoca는 각각 75 37.5 CFU/mL, 37.5 18.75 $\mathrm{CFU} / \mathrm{mL}$ 의 농도일 때 $0.015 \mathrm{EU} / \mathrm{mL}$ 이상의 endotoxin을 보유하 였다. 나머지 M. morganii, S. Typhi, S. sonnei베 비하여 현저히 적 은 endotoxin을 보유하고 있어 LAL 반응에 대한 end point가 높다 는 결과를 보인 것은 괄목할 만 하다. 이 두 군의 특징을 살펴보면 공 통점으로는 장내세균이고, 그람음성막대균이라는 것이며 차이점 중 두드러지는 특징으로는 E. coliO157와 K. oxytoca는 다른 세 균들과는 달리 유당분해 세균이라는 것이다. E. coli O 157 와 $K$. oxytoca는 대표적인 유당분해 세균이기 때문에 lac $Y$ 유전자를 가 지고 있으며 이로 인하여 galactoside permease를 생성한다. 이렇 게 생성된 효소를 이용하여 유당을 세포질로 유입시키게 된다. 이 렇게 유당분해를 위해 이들의 세포벽에 자리잡은 galactoside permease와 LPS는 모두 세포벽에 존재한다. 또 M단백질이 막단 백질 중 2 4\%정도로 높은 비율로 차지하고 있다는 점에서 보면 충 분히 상관관계가 있을 수도 있다고 사료된다. 아직까지 이 두 가지 물질에 대한 상관성에 대한 연구된 바는 전무하다. In vitro나 in vivo 실험에서 대식세포를 이용하여 염증을 유발시키는 경우에도 
상용화된 LPS를 사용한다[22,23]. 이만큼 LPS가 생체 내에서 즉각 적으로 반응을 보이기 때문이고 그만큼 위험하다는 것이다. 더욱이 병원성 세균의 경우에는 세균자체의 고유 병원성에 합병증으로 발 전할 수도 있기 때문에 충분한 주의가 필요하다. 세균내독소인 LPS 에 대한 연구는 앞으로도 큰 숙제로 남아 있으며 본 연구가 세균의 균종별 병원성 연구의 한 부분으로서 지속적인 연구의 계기가 될 수 있기를 기원한다.

\section{요 약}

세균내독소는 lipopolysaccharide (LPS)라고 불리우며, 그람음 성 세균의 세포벽에 존재하는 물질로 어느 생체재료나 액체에 존재 할 수 있다. 세균내독소가 혈액으로 침투되면 발열 및 염증을 유발 시킨다. 본 연구에서는 장내 그람음성세균인 Escherichia coli O157:H7, Klebsiella oxytoca, Salmonella Typhi, Shigella sonnei, Morganella morganii의 LPS 양을 비교하려 하였다. 각 세 균은 배양한 후 $1.5 \times 10^{8} \mathrm{CFU} / \mathrm{mL}$ 농도로 희석하여 동일한 농도로 하였으며 실험의 정당성을 위하여 LAL시약의 표시감도확인시험 을 진행하였다. 10 fold dilution 후 1 차 시험을 하여 각 균의 반응 end point를 확인하고 바로 윗단계 희석배수 사이에서 2 fold dilution하여 균의 최종 반응 end point를 확인하였다. 결과적으로 E. coli $\mathrm{O} 157$ 은 75 37.5 CFU/mL, K. oxytoca는 37.5 18.75 CFU/mL, M. morganii와 $S$. Typhi는 3.75 1.875 CFU/mL, $S$. sonnei는 7.5 3.75 CFU/mL에서 $0.015 \mathrm{EU} / \mathrm{mL}$ 이상의 endotoxin이 검출되었다. 최종적으로 억제인자에 대한 확인시험 을 진행하여 결과값을 보증하였다. 본 연구를 통하여 세균내독소에 대한 추가적인 연구가 지속되기를 기원한다.

Acknowledgements: 이 논문은 2016년도 원광보건대학교 교내 연구비 지원에 의해서 수행됨.

Funding: None

Conflict of interest: None

\section{References}

1. Kim ES, Kim SM, Cho JH. Characteristics on the toxicity of sonicated bacterial extracts, lipopolysaccharides, and bacterial growth supernatants of Prevotella nigrescens. Korean J Clin Lab Sci. 2003;35:14-21.

2. Lansing MP, John PH, Donald AK. Microbiology, 5th edition. New York: Mc Graw Hill; 2002, p411-419.

3. Lillehei RC, Longerbeam JK, Bloch JH. Physiology and therapy of bactermic shock, experimental an clinical observation. Am J
Cardiol. 1963;13:599-613.

4. Clas F, Loos M. Killing of the S and R forms of Salmonella minnesola via the classical pathway complement activation in guinea pig and human. Sera J immunology. 1980;40:547-556.

5. Lee YK, Kang YS, Baek SY, Kim YK. Comparison of LAL test with pyrogen test. Arch Pharm Res. 1999;43:606-613.

6. Cooper JF, Levin J, Wagner HN. Quantitative comparison of in vivo methods for the detection of endotoxin. J Lab Clin Med. 1971;78:138-148.

7. Wachtel RE, Tsuji K. Comparison of limulus amebocyte lysate and correlation with the United States pharmacopeial pyrogen test. Appl Environ Microbiol. 1977;33:1265-1269.

8. Steere AC, Rifaat MK, Seligmann EB, Hochstein Jr HD, Frieoland $\mathrm{G}$, Dasse P, et al. Pyrogen reactions associated with the infusion of 25\% normal serum albumin (human). Transfusion. 1978;18: 102-107.

9. Poole S, Dawson P, Gaines, Das RE. Second international standard for endotoxin : Calibration in an international collaborative study. J Endotoxin Research. 1997;4:221-231.

10. Riley LW, Remis RS, Helgerson SD, McGee HB, Wells JG, Davis BR, et al. Hemorrhagic colitis associated with a rare Escherichia coli serotype. N Engl J Med. 1982;308:681-685.

11. Kaphan BS, Cleary TG, Obrig TG. Recent advances in understanding the pathogenesis of the hemolytic uremic syndromes. Pediatr Nephrol. 1990;4:276-283.

12. Podschun R, Ullmann U. Klebsiella spp. as nosocomial pathogens: epidemiology, taxonomy, typing methods, and pathogenecity factors. Clin Microbiol Rev. 1998;11:589-603.

13. Amarjeet K, Smita S, Navin K, Sharmila S. Renal abscess caused by Salmonella Typhi. J Lab Physicians. 2015;7:121-123.

14. Formal SB, Levine MM. Shigellosis. In: Germajer R, editor. Bacterial vaccine. New York: Academic Press; 1984, p167-186.

15. Mastroianni A, Coronado O, Chiodo F. Morganella morganii meningitis in a patient with AIDS. J Infect. 1994;29:356-367.

16. Verboon-Maciolek M, Vandertop WP, Peters AC, Roord JJ, Geelen SP. Neonatal brain abscess caused by Morganella morganii. Clin Infect Dis. 1995;20:471.

17. Samonis G, Anatoliotaki M, Apostolakou H, Souglakos J, Georgoulias V. Fatal septisemia and meningitis due to Morganella morganii in a patient with Hodgkin's disease. Scand J Infect Dis. 2001;33:553-555.

18. Cooper JF, Weary ME, Jordan FT. The impact of non-endotoxin LAL-reactive materials on limulus amebocyte lysate analyses. PDA J Pharma Sci Tech. 1997;51:2-6.

19. Ikemura K, Ikegami K, Shimazu T, Yoshioka T, Sugimoto T. False positive result in limulus test caused by limulus amebocyte lysate-reactive material in immunoglobulin products. $\mathrm{J}$ Clin Microbiol. 1989;27:1965-1968.

20. Roslansky PF, Novitsky TJ. Sensitivity of limulus amebocyte lysate (LAL) to LAL-reative glucans. J Clin Microbiol. 1990;29: 2477-2483.

21. Choi, HJ, Yoo JL, Lee EH, Park JY, Prabagar MG, Park HS, Kang YS. Development of an improved endotoxin detection method using centrifugation. Korean J Microbiol Biotechnol. 2013;41: 242-248.

22. Kim YH, Lee GS. Effects of ionized radiation on nitric oxide production in embryonic mouse liver cell line BNL CL.2. Korean 
J Clin Lab Sci. 2000;32:214-222.

23. Yoon KN, Jang HS, Jin GH. Antioxidant, anti-diabetic, anti-cholinesterase and nitric oxide inhibitory activities of fruiting bodies of Agaricus brasiliensis. Korean J Clin Lab Sci. 2015; 47(4):194-202. 